\title{
RESOURCING INCLUSIVE EDUCATION
}




\section{INTERNATIONAL PERSPECTIVES ON INCLUSIVE EDUCATION}

\section{Series Editor: Chris Forlin}

\section{Recent volumes:}

Volume 1: Emotional and Behavioural Difficulties in Mainstream Schools Edited by John Visser, Harry Daniels and Ted Cole

Volume 2: Transforming Troubled Lives: Strategies and Interventions for Children with Social, Emotional and Behavioural Difficulties Edited by John Visser, Harry Daniels and Ted Cole

Volume 3: Measuring Inclusive Education - Edited by Chris Forlin and Tim Loreman

Volume 4: Working with Teaching Assistants and other Support Staff for Inclusive Education - Edited by Dianne Chambers

Volume 5: Including Learners with Low-Incidence Disabilities - Edited by Elizabeth A. West

Volume 6: Foundations of Inclusive Education Research - Edited by Phyllis Jones and Scot Danforth

Volume 7: Inclusive Pedagogy Across the Curriculum - Edited by Joanne Deppeler, Tim Loreman, Ron Smith and Lani Florian

Volume 8: Implementing Inclusive Education - Edited by Amanda Watkins and Cor Meijer

Volume 9: Ethics, Equity and Inclusive Education - Edited by Agnes Gajewski

Volume 10: Working with Families for Inclusive Education: Navigating Identity, Opportunity and Belonging - Edited by Dick Sobsey and Kate Scorgie

Volume 11: Inclusive Principles and Practices in Literacy Education - Edited by Marion Milton

Volume 12: Service Learning: Enhancing Inclusive Education - Edited by Shane Lavery, Dianne Chambers and Glenda Cain

Volume 13: Promoting Social Inclusion: Co-Creating Environments That Foster Equity and Belonging - Edited by Kate Scorgie and Chris Forlin

Volume 14: Assistive Technology to Support Inclusive Education - Edited by Dianne Chambers 
INTERNATIONAL PERSPECTIVES ON INCLUSIVE

EDUCATION VOLUME 15

\title{
RESOURCING INCLUSIVE EDUCATION
}

\author{
EDITED BY \\ JANKA GOLDAN \\ Faculty of Educational Sciences, University of Bielefeld, \\ Germany

\section{JENNIFER LAMBRECHT} \\ Berliner Kita-Institut für Qualitätsentwicklung \\ (Berlin Kindergarten Institute for Quality Development), \\ Germany

\section{TIM LOREMAN}

Faculty of Education, Concordia University of Edmonton, Canada

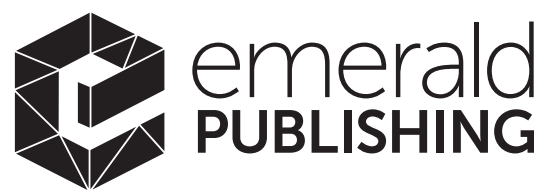

United Kingdom - North America - Japan India - Malaysia - China 
Emerald Publishing Limited

Howard House, Wagon Lane, Bingley BD16 1WA, UK

First edition 2021

Copyright (C) 2021 Emerald Publishing Limited

\section{Reprints and permissions service}

Contact: permissions@emeraldinsight.com

No part of this book may be reproduced, stored in a retrieval system, transmitted in any form or by any means electronic, mechanical, photocopying, recording or otherwise without either the prior written permission of the publisher or a licence permitting restricted copying issued in the UK by The Copyright Licensing Agency and in the USA by The Copyright Clearance Center. Any opinions expressed in the chapters are those of the authors. Whilst Emerald makes every effort to ensure the quality and accuracy of its content, Emerald makes no representation implied or otherwise, as to the chapters' suitability and application and disclaims any warranties, express or implied, to their use.

\section{British Library Cataloguing in Publication Data}

A catalogue record for this book is available from the British Library

ISBN: 978-1-80043-457-8 (Print)

ISBN: 978-1-80043-456-1 (Online)

ISBN: 978-1-80043-458-5 (Epub)

ISSN: 1479-3636 (Series)

\section{ISOQAR certified}

Management System,

awarded to Emerald

for adherence to

Environmental

standard

ISOQAR

ISO 14001:2004. 


\section{CONTENTS}

About the Authors

About the Editors

\section{SECTION 1 FUNDING AND RESOURCING INCLUSIVE EDUCATION}

A Winning Formula? Funding Inclusive Education in Ireland Joanne Banks

Quality Early Child Education Mitigates against Special Educational Needs in Children

Gabrielle D. Young, David Philpott, Sharon C. Penney, Kimberly Maich and Emily Butler

What's in the Budget?: A Look at Funding for Inclusive Initiatives in ESSA and IDEA

Nicholas Catania, Danielle Lane, Sarah Semon, Sharlene Smith and Phyllis Jones

Global Trends in the Funding of Inclusive Education: A Narrative Review

Umesh Sharma and Samantha Vlcek

Resources for Inclusive Education in Austria: An Insight Into the Perception of Teachers

Marie Gitschthaler, Julia Kast, Rupert Corazza and Susanne Schwab 
A Matter of Resources? - Students' Academic Self-Concept, Social Inclusion and School Well-being in Inclusive Education Janka Goldan, Lisa Hoffmann and Susanne Schwab

\section{SECTION 2 PROFESSIONAL DEVELOPMENT FOR INCLUSIVE EDUCATION}

Transitioning from Segregation to Inclusion: An Effective and Sustainable Model to Promote Inclusion, through Internal Staffing Adjustments, and Role Redefinition

Sheila Bennett, Tiffany L. Gallagher, Monique Somma, Rebecca White and Kathy Wlodarczyk

Soka Education Philosophy as a Foundation for Teacher Preparation in Creating Inclusive Education

Joseph Seyram Agbenyega, Kiiko Ikegami and Corine Rivalland

Teacher Training for Inclusive Education in Germany: Status Quo and Curricular Implementation

Saskia Liebner and Claudia Schmaltz

Enhancing Teacher Education by Utilizing a Revised PGDE Curriculum as a Fundamental Resource for Inclusive Practices in Macao

Elisa Monteiro and Chris Forlin

Index 


\section{ABOUT THE AUTHORS}

Dr Joseph Seyram Agbenyega (EdD) is an Associate Professor of special education in the Division of Special Education, Guidance and Counselling and Education Neuroscience at Emirates College for Advanced Education (ECAE), Abu Dhabi, UAE. Before joining ECAE, Professor Agbenyega was the Director of Graduate Research Education at Monash University, Australia. His research focus is special education. He is interested in the psychological and sociological understandings of educational inclusion and inequality among children and youth. He explores how policy and government support for education orchestrate educational equity and quality.

Dr Joanne Banks is a lecturer and researcher in inclusive education at the School of Education in Trinity College Dublin. She has worked for over a decade in social research focussing on inclusive education, the school experiences of students with disabilities and educational inequality more generally. Her research focusses on inclusive education in policy and practice and examines system and school-level practices that promote quality and equity for all students. She has published widely on the school experiences of students with disabilities and those from socio-economically deprived backgrounds. Her work has been published in journals such as Educational Assessment, Evaluation and Accountability, Child Indicators Research, British Journal of Sociology of Education, Journal of Youth Studies, International Journal of Inclusive Education, European Journal of Special Needs Education and Irish Educational Studies.

Dr Sheila Bennett, D. Ed., is a Professor and Former Associate Dean of Professional and Undergraduate Programs Faculty of Educational Studies at Brock University, Canada. She has presented nationally and internationally and has authored and co-authored numerous books, chapters, monographs and articles including Special Education in Ontario Schools; including Students with Exceptionalities and A Canadian Perspective on the Inclusion of Students with Intellectual Disabilities in High Schools. Her research centres on inclusion for students with diverse needs. Upon completion of her graduate work at the University of Toronto, Dr Bennett held a number of school and school board-based positions prior to joining the Faculty of Educational Studies at Brock. She brings her practical experiences as an educator to the field of research, providing a blend of theory and practice essential to bridge the gap between what we do in classrooms and how we understand those actions in the larger context.

Emily Butler has a Master of Education (Counselling Psychology) from MUN, a Bachelor of Arts degree with a major in psychology and a Bachelor of Education. 
She is a registered psychologist (provisional) and is interested in child psychology, play therapy and inclusive programmes for children with mental health concerns or special educational needs in early years' settings and K-12 school system.

Nicholas Catania is a doctoral candidate in special education at the University of South Florida (USF). His research interests include teacher preparation for social justice as well as pedagogical practices for meeting the needs of LBGTQ students. He has over 10 years of experience teaching in K-12 and higher education settings. Nicholas is also a visiting instructor for the Elementary Education programme at USF where he works with teacher candidates in their field placements providing them best practices while coaching them to improve their teaching skills. He has also presented his research at many national conferences.

Dr Rupert Corazza, Board of Education for Vienna, Austria, is an educational researcher and political advisor at the Board of Education for Vienna. As a member of the expert staff, he currently leads the implementation process of an extensive education reform in the field of special educational needs. He holds a doctorate in education and a master's degree in Philosophy. He is also lecturer at University College of Teacher Education in Vienna. Dr Corazza conducted numerous national and international research projects in the field of philosophy of education and student assessment. In a current project he develops an assessment tool for children with special educational needs according to ICF-CY. Drawing on Goffman's concept of framing, he regularly publishes scientific articles on the stigmatizing effects of educational categories like school dropout or learning disability.

Professor Chris Forlin is an international education consultant specializing in supporting governments and school systems to implement effective and quality inclusive education. She has worked in the field of education for more than 40 years as a teacher, university lecturer and government advisor. Her work with teachers is extensive and she is a frequently sought after as a keynote conference presenter. Her extant research and publications focus on policy development for education reform and systemic support for children and youth with disabilities and development of inclusive curriculum and pedagogy with a particular emphasis on inclusion in developing countries. Her most recent book, published by Emerald, Promoting social inclusion: Co-creating environments that foster equity and belonging was published in the International Perspectives on Inclusive Education series that she edits.

Tiffany L. Gallagher, $\mathrm{PhD}$, is a Professor in the Department of Educational Studies at Brock University, Canada. Prior to this role, Tiffany taught in two school boards in Northern Ontario. Then, for 13 years, she was an administrator in private practice supplemental education providing remedial instruction for students with learning difficulties. She is recognized for her research that aims to enhance the learning of students with literacy difficulties and learning challenges. Supporting the professional learning of teachers through instructional and inclusion coaching are also a focus of her work. Longitudinal, multi-varied 
participant perspectives are the cornerstone of Tiffany's research projects. Her work seeks to inform targeted audiences such as students, teachers, administrators and policy makers. She has published more than 50 refereed articles/chapters, as well as eight books. Tiffany is also the director of the Brock Learning Lab that offers community-based tutoring for K-12 students and mentors undergraduate volunteer tutors.

Dr Marie Gitschthaler, Paderborn University, Germany, is an educational researcher at the Specialist Department for Inclusion, Diversity and Special Educational Needs at the Board of Education for Vienna since 2019 and is involved in the implementation process of an extensive education reform in the field of special education. Currently, she holds the position of an interim professor for Special Education with a focus on learning at University of Paderborn. For a decade, she worked as a researcher and lecturer at the Education Sciences Group at Vienna University of Economics and Business. Dr Gitschthaler conducted numerous national and international research projects on the causes of school dropout, the individual and social costs of inadequate education, social exclusion, education policies concerning inequality and good practices in school improvement. She is highly experienced in conducting longitudinal mixedmethods studies.

Lisa Hoffmann is a $\mathrm{PhD}$ student at the Institute for Educational Research at the University of Wuppertal, Germany, and special education teacher. Her research mainly focusses on the social participation of students with special educational needs in inclusive settings.

Kiiko Ikegami (PhD) is an Assistant Professor at the University of Saint Joseph, Macau, China. She is the Head of the School of Education and Programme Coordinator for the Master of Education at the University of St Joseph, Macau. Prior to moving to Macau, Kiiko was a teaching associate at the Faculty of Education, Monash University. Her specific research focusses on quality early childhood education theorized through the Soka education model and how educator's knowledge, beliefs and pedagogy practices contribute to quality education for young children.

Dr Phyllis Jones is a Professor in the Department of Teaching and Learning at the University of South Florida (USF). Phyllis taught and was a deputy head in schools in the UK for 15 years before she entered teacher education. She came to USF in 2003. She is author of Curricula for Students with Severe Disabilities: Narratives of Standards-Referenced Good Practice, Inclusion in the Early Years: Stories of Good Practice, co-author of Collaborate Smart and lead editor of A Pig Don't Get Fatter the More You Weigh It: Balancing assessment for the classroom, Leading for Inclusion, Creating Meaningful Inquiry in the Inclusive Classroom, Pushing the Boundaries: Developing Inclusive Practices through Integration of Insider Perspectives, co-editor of The Routledge Companion to Severe, Profound and Multiple Learning Difficulties and The Foundations of Inclusive Education Research. She is co-editor of International Journal of Whole Schooling, sits on the 
editorial board of Disability \& Society and is a regular reviewer for British Journal of Special Education, Journal of Child and Family Studies, International Journal of Inclusive Education, Journal of Teacher Education and International Review of Education. Internationally, she has worked in England, Ireland, New Zealand, Thailand and Mexico. Phyllis has a current Fulbright application and has been successful at the US country level, with her application having been forwarded to Hong Kong for this review.

Julia Kast, MA, University of Vienna, Austria, has started her PhD at the Centre for Teacher Education at University of Vienna in 2018. Her research mainly focusses on inclusive education. In 2013, she graduated from Psychology with a focus on Educational Psychology at University of Vienna. Further topics include teachers' attitudes towards inclusive education and teachers' self-efficacy in inclusive educational settings. Her doctoral thesis focusses on the inclusion of students with different language abilities within the Austrian Education system.

Dr Danielle Lane is an Assistant Professor of special education at Elon University in North Carolina. Her research focusses on global understandings of disabilities in various cultural contexts. Specifically, she is interested in centralizing the importance of inclusive practices in educational provisions that are provided to students with disabilities. Danielle teaches courses in special education at the undergraduate level and serves as a university supervisor for pre-service teacher candidates. She also serves as the editorial assistant for International Journal of Whole Schooling.

Kimberly Maich, PhD, OCT, BCBA-D, is a Professor in the Faculty of Education at MUN, a certified teacher, a special education specialist, a board-certified behaviour analyst and a registered psychologist (provisional). Her research and writing is focused on special education in general and autism spectrum disorders, emotional/behaviour disorders, early learners and assistive technology more specifically. She engages in qualitative, mixed-methods and single case quantitative experimental research design and is committed to community-based knowledge mobilization of research findings and the use of case study in teaching and learning.

Elisa Monteiro is an Associate Professor in the Faculty of Social Sciences and Education in the University of Saint Joseph, Macao. She teaches various modules in the undergraduate and postgraduate education programmes and supervises inservice and pre-service teachers during their teaching practice at placement schools. Professor Monteiro has delivered several teacher professional development courses and workshops in the areas of instructional pedagogy and assessment. Most of her work has been developing and articulating teachers' professional knowledge and skills. Her research interests cover a range of topics in curriculum planning, pedagogy, instructional strategies, blended learning, assessment and inclusive education.

Saskia Liebner is a postdoc lecturer in the Faculty of Human Sciences, Unit Inclusion and Organization Development, at the University of Potsdam 
(Germany). Her current research is concerned with teacher training and the professional development of pre- and in-service teachers in the field of inclusive education.

Sharon C. Penney, PhD, is an Associate Professor in the Faculty of Education at MUN, a certified teacher and registered psychologist with the Newfoundland and Labrador Psychology Board. Her research is focused on special education, autism spectrum disorders, home and school partnerships as well as positive mental health. She works primarily with qualitative methodologies and mixedmethods research.

David Philpott, EdD, is a Professor in the Faculty of Education at MUN and has enjoyed a career of more than 35 years in education and child development. He has worked in a range of teaching and management positions in special education, including a 25-year clinical practice in child mental health and assessment. He has an extensive national and international research/publication portfolio in areas such as inclusive education, assessment, Indigenous/Aboriginal education, family empowerment, international students, early child education and teacher training.

Corine Rivalland $(\mathrm{PhD})$ is a lecturer in Early Childhood and Equity and Social Justice Education in the Faculty of Education, Monash University. Her research focus addresses alternative theories of child development and equity and social justice. Her work aims to contribute to the early childhood educational research with the view of implementing more equitable and socially just early childhood teaching and learning practices.

Claudia Schmaltz is a secondary school teacher in Baden-Württemberg, Germany. She completed her PhD at the University of Education, Freiburg, on the effect of in-service training on the teaching planning competence of teachers, with a particular focus on heterogeneity as a challenge for teaching.

Susanne Schwab is a Full Professor at the Centre for Teacher Education, University of Vienna, Austria, and extraordinary professor at the Research Focus Area Optentia, North-West University, Vanderbijlpark, South Africa. Her research specifically focusses on inclusive education, as well as teacher education and training. She has recently published a chapter about 'Inclusive and special education in Europe' in the Oxford Research Encyclopedia of Education.

Sarah Semon earned her PhD in Curriculum and Instruction in Special Education from the University of South Florida. She is a visiting instructor of special education in the Department of Teaching and Learning at USF and has over 20 years of experience teaching in K-12 and higher education settings. Sarah has dedicated her career to improving inclusive education services for diverse learners. She has extensive experience consulting, writing and managing federal and state grant projects. She has presented educational research findings at national conferences and has co-authored numerous journal articles and book chapters. 
Umesh Sharma is Professor in the Faculty of Education at Monash University, Australia, where he is the academic head of the Educational Psychology and Inclusive Education Community. Umesh's research programmes in the area of disability and inclusive education span India, Pakistan, China, Bangladesh, Fiji, Solomon Islands, Vanuatu and Samoa as well as Australia, Canada, USA and New Zealand. He is the chief co-editor of the Australasian Journal of Special Education and the Oxford Encyclopedia of Inclusive and Special Education. His co-authored book A Guide to Promoting a Positive Classroom Environment was the recipient of the International Book Prize Award from the Exceptionality Education International. He was recently (2019) named the top special education researcher in Australia based on the impact of his work locally and internationally by the Australian Chief Scientist https://specialreports.theaustralian.com.au/1540291/.

Sharlene Smith earned her $\mathrm{PhD}$ in Curriculum and Instruction in Adult Education, and cognate in Autism Spectrum Disorder from the University of South Florida. She is a behaviour specialist at the Rutgers University Centre for Adult Autism Services. She is an advocate for inclusive and equitable communities to ensure every student receives the requisite resources to achieve success. For the past five years, she has been working with individuals with disabilities, specifically autism, and their families. Dr Smith is also a national and international scholar. She co-authored several peer-reviewed journals and book chapters. Her research centres on the adult education of general and special needs population. Some of her present research focus includes the professional development and continuing education of educators who work with individuals with special needs. She also serves as a reviewer for the International Journal of Whole Schooling.

Monique Somma, PhD, OCT, is an Assistant Professor and emerging scholar in the Department of Educational Studies at Brock University, Canada. Currently, she co-develops and teaches courses to teacher candidates on topics including child development, cognition and the inclusion of students with exceptionalities, in order to help prepare future teachers to effectively meet the needs of diverse learners in the classroom. Her research focusses on preschool to secondary educator preparedness for inclusive education, from attitudes and beliefs to learning and practice. She is the co-author of Special Education in Ontario Schools, eighth edition, 2019.

Samantha Vlcek is a research assistant at Monash University and is currently completing her $\mathrm{PhD}$ in the field of inclusive education at the University of Tasmania. She holds a BEd with first class Honours and a Graduate Certificate in Research. Samantha has taught in both primary schools and at a tertiary level. Her research and teaching are concerned with inclusive education and supporting the education of students with diverse needs. Samantha has comprehensive knowledge of disability legislation and policy, as well as a deep understanding of implementing evidence-based practices to support student experience and outcomes. 
Rebecca White, BA, has completed a joint honours degree at the University of Ottawa, Canada, in history and political science. She is currently a project coordinator, research assistant and completing her Masters of Education at Brock University with a specialization in administration and leadership. Rebecca's research interests focus on improving inclusive education for students with exceptionalities in both policy and practice.

Kathy Wlodarczyk, PhD, has completed her studies at McMaster University, Canada. Her research, clinical and scholarly work focusses on understanding the mechanisms that contribute to effective outcomes and best practices in collaborative partnerships between the disciplines of rehabilitation and education. Kathy's work is edified with an inclusive, holistic and multidisciplinary lens.

Gabrielle D. Young, $\mathrm{PhD}$, is an Associate Professor in a Canadian Faculty of Education, Memorial University of Newfoundland (MUN), where she teaches undergraduate and graduate courses surrounding understanding and supporting students with specific learning disorders, as well as the practicum in special education. Gabrielle's research interests surround the use of assistive and instructional technology in inclusive classrooms, applying the principles of universal design for learning to support students with exceptionalities in the general education classroom, and pre-service teachers' efficacy to support students in inclusive classrooms and facilitate positive mental health. 
This page intentionally left blank 


\section{ABOUT THE EDITORS}

Janka Goldan, $\mathrm{PhD}$, is a Researcher at the Faculty of Educational Science, University of Bielefeld. She studied in Frankfurt (GER) and London (UK) and holds degrees in education and business administration. Her research focusses on inclusive education, including funding and resourcing of special needs education. She received her PhD from the University of Wuppertal (GER) and is involved in several projects, among them also in education policy. Her key publications address issues of resourcing inclusive education and the assessment of resource perceptions.

Jennifer Lambrecht, $\mathrm{PhD}$, is a Researcher at the Faculty of Educational Science, University of Potsdam, Germany. She studied in Hamburg and Berlin and holds degrees in education and philosophy. Her research focusses on inclusive education, educational inequalities and the role of institutional learning environments. In her dissertation, she developed a theory on inclusive education. Furthermore, she is involved in several projects, including science communication.

Tim Loreman, $\mathrm{PhD}$, is President and Vice-Chancellor, and Professor of Education, at Concordia University of Edmonton. He studied at Monash and Deakin Universities in Melbourne, Australia. His active research interests include inclusive education, teacher education and pedagogy. In 2010, he was senior visiting research fellow at the University of Bologna and in 2013 was visiting research professor at Queens University Belfast. He has held a number of major Canadian research grants and participated in large cross-institutional and crossnational projects aimed at reform of education systems in Ukraine and various Pacific Island nations in order to better support inclusive education. 
This page intentionally left blank 


\title{
SERIES INTRODUCTION
}

\author{
Edited by Janka Goldan, Jennifer Lambrecht and Tim Loreman
}

The adoption internationally of inclusive practice as the most equitable and all-encompassing approach to education and its relation to compliance with various international declarations and conventions underpins the importance of this series for people working at all levels of education and schooling in both developed and less developed countries. There is little doubt that inclusive education is complex and diverse and that there are enormous disparities in understanding and application at both inter- and intra-country levels. A broad perspective on inclusive education throughout this series is taken, encompassing a wide range of contemporary viewpoints, ideas and research for enabling the development of more inclusive schools, education systems and communities.

Volumes in this series on International Perspectives on Inclusive Education contribute to the academic and professional discourse by providing a collection of philosophies and practices that can be reviewed considering local contextual and cultural situations in order to assist governments, educators, peripatetic staff and other professionals to provide the best education for all children. Each volume in the series focusses on a key aspect of inclusive education and provides critical chapters by contributing leaders in the field who discuss theoretical positions, quality research and impacts on school and classroom practice. Different volumes address issues relating to the diversity of student need within heterogeneous classrooms and the preparation of teachers and other staff to work in inclusive schools. Systemic changes and practice in schools encompass a wide perspective of learners to provide ideas on reframing education to ensure that it is inclusive of all. Evidence-based research practices underpin a plethora of suggestions for decision-makers and practitioners, incorporating current ways of thinking about and implementing inclusive education.

While many barriers have been identified that may potentially constrain the implementation of effective inclusive practices, this series aims to identify such key concerns and offers practical and best practice approaches to overcoming them. Adopting a thematic approach for each volume, readers will be able to quickly locate a collection of research and practice related to a topic of interest. By transforming schools into inclusive communities of practice, all children can have the opportunity to access and participate in quality and equitable education to enable them to obtain the skills to become contributory global citizens. This series, therefore, is highly recommended to support education decision-makers, practitioners, researchers and academics, who have a professional interest in the 
inclusion of children and youth who are marginalizing in inclusive schools and classrooms.

Volume 15 in the International Perspectives on Inclusive Education series adds to the collection by addressing a very demanding aspect of how to resource inclusive education to ensure it is equitable, fair, manageable and effective. All governments and education departments are faced with issues surrounding resourcing inclusive education, usually within a defined budget and fiscal constraints. This is heightened further for financial administrators, during transition periods where governments are moving from a segregated to a more inclusive education system. By critiquing an extensive range of optional funding models, funding formulas and human resourcing approaches, this book offers a comprehensive review of how appropriate resourcing, within a country's given restraints and specific cultural and contextual issues, can support more effective inclusive education.

Presented in two sections, the authors firstly address the evolving challenges associated with funding inclusive education by considering evidence from a range of countries which have endeavoured to respond to these in diverse and positive ways. The issues of developing effective policy and of establishing accountability mechanisms that ensure equitable distribution of funding across all schools are treated empathetically, citing relevant and useful research and evidence. The latter half of the book provides a life-long learning perspective on how to improve inclusion by focussing on enhanced human resourcing through better teacher education and professional learning. The importance of appropriate and effective teacher education for inclusion has been identified in all systems. Key international documents continue to highlight that inclusive education requires teachers who are appropriately trained, motivated, enjoy teaching and who are backed by well-managed and resourced education systems. Any inclusive educational reform model must be focussed on these areas. Both sections of the book are, therefore, critical, as the dynamic interaction between the two is essential to ensuring effective and sustainable implementation of quality inclusive education.

A tangible strength of this volume is that it explicitly contemplates resourcing inclusive education through the application of realistic funding approaches and improved professional learning. Of importance, though, is that while focussing on dollar expenditure, it also considers how better resourcing will help students to develop twenty-first century skills of academic self-concept, social inclusion and general well-being. It also highlights the strong link between effective funding management and teachers' self-efficacy and attitudes towards becoming effective and positive inclusive practitioners.

Volume 15 is a critical book for all stakeholders concerned with how to resource inclusive education, to provide quality education for all learners. This is addressed effectually through reviewing how resourcing can be managed to ensure equitable access regardless of geographical region or students' needs. This book provides excellent, current and practical approaches while reviewing global trends that will appeal to support school staff, administrators, economists, district coordinators, other stakeholders and school board personnel to make best possible decisions regarding funding regimes. This volume will also appeal to 
university academics, students and researchers who are tasked with investigating best practice ways of resourcing inclusive schools. Within the book, selected chapters enable the reader to choose a specific area of resource interest and to explore options derived from research and best practice evidence-based ideas presented by leading international experts in the field. Volume 15 will be an important international resource providing immediate access to a wide range of germane approaches across many disciplines to enable good decisions to be made to better resource inclusive education. I highly recommend and endorse it as an excellent addition to the International Perspectives on Inclusive Education series.

Chris Forlin Series Editor 